\title{
環境適応ソフトウェア実現に向けた全体フロー提案
}

\author{
山登 庸次 ${ }^{\mathrm{a}, *}$
}

\section{Processing Flow of Software Adaptation Based on Deployed Environment}

\author{
Yoji Yamato ${ }^{a, *}$
}

(Received June 6, 2020; revised July 7, 2020; accepted July 20, 2020)

\begin{abstract}
Recently, heterogeneous hardware such as GPU and FPGA utilization is increased in systems. However, to utilize them, the hurdles are high because of much skill. Therefore, I propose environment adaptive software to operate an application with high performance by automatically converting the code and configuring so that we can utilize heterogeneous hardware easily.
\end{abstract}

キーワード : 環境適応ソフトウェア，GPGPU，FPGA，自動オフロード，性能

Keywords : Environment Adaptive Software, GPGPU, FPGA, Automatic Offloading, Performance.

\section{1.はじめに}

近年，ムーアの法則が鈍化すると言われている。その 状況も踏まえ, GPU やFPGA といったへテロなハードウ エアをシステムに用いることが増えており(1), それを用 いたサービスも IoT やサービス連携技術(2)-(4)等により 数多く開発されている。しかし，ヘテロなハードウェア を様々なアプリケーションで活用して，高性能に運用す るためには，ハードウェアに合わせたプログラムや設定 が必要で, CUDA, OpenCL 等(5)高度技術が求められる。

本稿は, アプリケーションを高性能に運用するため, コード変換や設定を配置環境に合わせて自動で行う，環 境適応ソフトウェアを提案する。これにより, GPU, FPGA 等のハードウェアを容易に活用することを目指す。本稿 貢献は, 新規な環境適応ソフトウェア全体フロー提案で あり，個々の要素技術の詳細提案，評価は別稿に譲る。

2. 環境適応ソフトウェアの処理フロー

ソフトウェアの環境適応には, コード変換, リソース 量/配置場所の設計, 運用時環境適応が必要と考えている。 これらは, 現在, SIer が手動で行っている領域である。 例えばコード変換では, 根本的課題として, どの部分を オフロードすれば高速化できるかの判断は，スキル，経

\footnotetext{
* Corresponding author. E-mail: yoji.yamato.wa@hco.ntt.co.jp

a 日本電信電話（株） ネットワークサービスシステム研究所

干180-8585 東京都武蔵野市緑町 3-9-11

Network Service Systems Laboratories, NTT Corporation

3-9-11, Midori-cho, Musashino-shi, Tokyo, Japan 180-8585
}

験が必要で, CUDA や OpenCL を熟知した技術者が手動 設計しているのが基本である。本稿では，これらのステ ップを機械により自動で行う事が最大の差異点である。 これらの処理を実現する処理フローを,図 1 で説明する。

Step1 コード分析: ユーザは動作させたいアプリケーシ ヨンコードと利用を想定したテストケース, 要望する性 能とコストを，環境適応機能に指定寸る。環境適応機能 は, コードを分析する。分析では, ループ文や変数の参 照関係，処理する機能ブロック等の，構造を把握する。

Step2 オフロード可能部抽出: 環境適応機能は, アプリ ケーションコードの並列処理可能なループ文や FFT 処理 等の機能ブロック等, オフロード可能な処理をコードパ ターン DB を参照して特定し, オフロード先に応じた中 間言語 (OpenCL 等) を抽出する。なお, 中間言語抽出は 一度で終わりでなく, 適切なオフロード領域探索のため, 検証環境で試行して最適化するため反復がされる。

Step3 適切なオフロード部探索: 次に, 環境適応機能は, GPU や FPGA，IoT デバイス用 GW 等を備えた検証環境 に, 中間言語から導かれる実行ファイルを配置する。配 置ファイルを起動し，テストケースを実行して，オフロ ードした際の性能を測定する。ここで, GPU やFPGA 等 オフロード先に応じて, 性能結果を参照して, より適切 なオフロードとするため, Step2の中間言語抽出に戻り, 別パターン抽出を行い, 性能測定を試行する。検証環境 での性能測定を繰り返し，最終のコードを決定する。

Step4 リソース量調整: コードパターンを決定後は, 環 境適応機能は, 適切なリソース量の設定を行う。Step3 


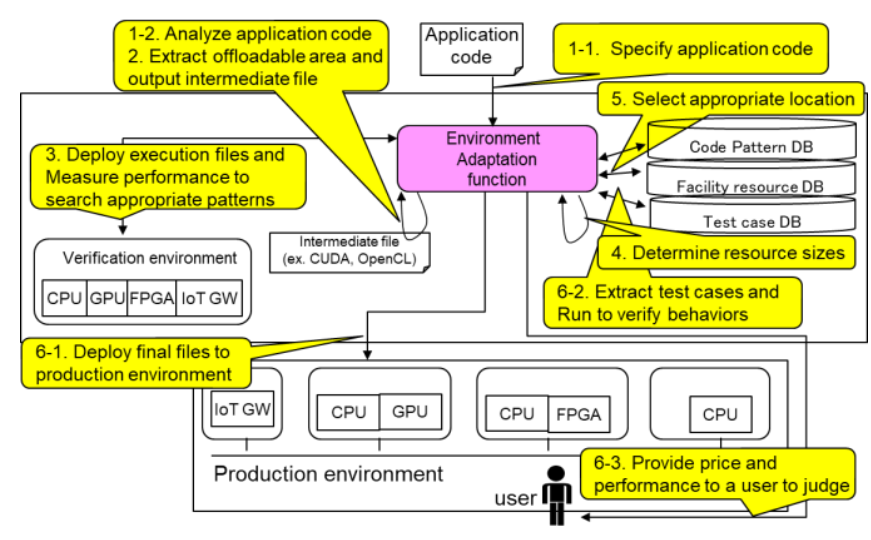

Fig. 1. Processing flow of environment adaptive software.

の検証環境性能測定で取得される，想定テストケースの 処理時間の中で, $\mathrm{CPU}$ 処理時間と GPU 等の CPU 以外八 ードウェアの処理時閒を分析し，適切なリソース比を定 める。次に, ユーザの要望する性能, コストと適切なリ ソース比を鑑みて, 実際に確保するリソース量を定める。

Step5 配置場所調整: 実行ファイルを配置する際に, 環 境適応機能は, 性能, コストが適切になる場所を計算し 配置先を決める。実行するアプリケーションの想定する テストケースの特性, 設備リソース DB の情報から, 性 能とコストが適切になる配置場所を計算する。ここで, 配置場所（エッジ等）に，リソース量制限から，必要な リソースを確保できない場合は，Step4に処理を戻す。

Step6 実行ファイル配置と動作検証：商用環境に配置 後, 期待通りの動作となるかを, 環境適応機能は, 動作 検証試験を行う。想定テストケースや，テストケース DB に保持されているリグレッションテストケースを用いて， 動作検証する。この際に，テストケースの商用環境での 実性能を, 確保した全リソースのスペックやコストも含 めて, ユーザに提示し，ユーザにサービス開始判断をも らい, OKの場合にアプリケーションの運用を開始する。

Step7 運用中再構成: 開始した運用にて, リクエスト特 性変化等で当初の性能が出ない場合に, 環境適応機能は, ソフトウェア設定，ソフトウェア/ハードウェア構成を再 構成する。ソフトウェア設定とは, リソース量や配置場 所の再変更を意味し, ソフトウェア/ハードウェア構成と は, GPU ではオフロードする処理部分を, FPGA では八 ードウェアロジックを再構成することを意味する。

本全体フローは, 全ステップが実装できているわけで はない。しかし，一部は実装しており，Step1-3 を GPUに 適用した例として(6)がある。(6)では, 映像認識を深層学 習で行う Darknetの 3 倍自動高速化を行っており，動体 展示も NTT R\&D フォーラム 2018 秋に展示された。

3. 環境適応ソフトウェア処理フローの要素技術

\section{1 コード変換}

Step1 のコード分析については, Clang(7)-(9)等の構文
解析ツールを用いて, 分析を行う。分析は, ループ文や 変数の参照関係等のコードの構造や, FFT 処理等の特定 処理を行う機能ブロックである事や特定処理のライブラ リを呼び出している等を把握する。機能ブロックの判断 には, Deckard(10)等の類似性検知ツールを用いる。オフ ロード性能は, 最大性能になる設定を一回で発見するの は難しいため, 性能測定を検証環境で繰り返し試行し, 高速化パターンを見つけることを，Step2，3で行う。

(a) GPU 向けオフロード

私達は既に，GPU 自動オフロード方式を提案している (6)(11)。提案方式では, GPU 処理に適切なループ文を, 検証環境での繰返し測定により抽出を行うが，その際に 進化計算手法の一つである遺伝的アルゴリズムを用いて 探索を行っている。さらに, CPU と GPU 間のメモリデ 一夕転送を削減するため, ネストループ内の変数で一括 化できる変数は一括転送を行っている。(11)では行列計 算等の小アプリについて 10 倍以上, (6)では Darknet 等の 大規模アプリについて 3 倍以上高速化を実現している。

(b) FPGA 向けオフロード

FPGA のオフロードは, 多くはアプリケーションに依 存するため, 機械がオフロードロジックを抽出するのは 難しい。そこで, FPGA では, 今までにプログラマーが蓄 積したノウハウ（Well-known パターン）を生かすため, 機能ブロックでオフロードする。Step1 のコード分析で把 握した機能ブロックがコードパターン DB に登録されて いる場合に, 登録 FPGA ロジックに置換してオフロード する。この置換のため, コードパターン DB は, FPGAに オフロード可能な処理のライブラリ呼び出しや機能ブロ ックと, オフロードする FPGA 処理ロジックの OpenCL コードを, 登録している。もし，オフロード機能ブロッ クが見つからない場合は, GPU と同様ループ文を試行す るが，ROSE(12)等の Arithmetic Intensity ツールで測定し た計算密度が高いループ文を優先的に試行する。

\section{2 リソース量調整}

Step4 のリソース量調整については, まず適切なリソー ス比を決め, 次に性能, コスト要件に合うリソース量に 設定する。例えば, CPU と GPU で動作させるコードに 変換したとして, CPU と GPU のリソース量が適切なバ ランスでない場合は, 性能が出ない。(13)では, CPU と GPU で MapReduceを行う際, CPUとGPUの実行時閒が 同じになる Map タスクを配分し高性能化している。私達 も, リソース比を決める際は, (13)等を参考に, 何れかの ハードウェアでの処理がボトルネックとなる配置を避け るため, CPU とオフロード先の測定処理時間が同等で適 切なオーダーになるよう, リソース比を決定する。リソ 一ス比決定後は, 想定テストケースの処理性能が, Step1 でユーザ指定の要求性能及びコスト要求を満たす様に, リソース比はキープして, リソース量を決定する。 


\section{3 配置場所調整}

Step5 の配置場所調整では, 性能, コストが適切な場所 を計算し配置先を決める。配置先を決めるため, 配置ア プリケーションの想定テストケースの性能情報（処理遅 延やスループット) と, 利用できる設備リソース情報（ク ラウド，エッジ，Home GW 等の計算リソース，帯域，既 利用量, 利用コスト）がある。想定テストケースの性能 結果から，アプリケーションを配置した際の計算量と発 生トラフィックをまず算出する。合わせて, クラウド, エッジ等のリンク関係をモデル化しておく。アプリケー ションを特定ノードに配置した際，コストが要求条件に 収まる事を制約条件に, 性能を最大化する配置, 又は, 性能が要求条件を満たす形でコストが最低になる配置を, 線形計画手法等の最適化計算を用いて計算する。

\section{4 動作検証}

Step6 の動作検証では, Step1-3 で決まった実行ファイ ルをStep4 の指定リソース量で Step5 の指定場所に配置 した後に，期待通りの動作を，性能テストケースやリグ レッションテストケースで確認する。性能テストケース は，ユーザが指定した想定テストケースをJenkins(14)等 の自動実行ツールを用いて行い, 処理時間やスループッ ト等を測定する。リグレッションテストは，システムに インストールされるミドルウェアや OS 等のソフトウェ ア情報を取得して対忘リグレッションテストを実行する 自動検証技術が検討されており(15), それらを用いる。

\section{5 運用中再構成}

Step6の運用開始後, リクエスト特性変化等で当初の性 能が出ない場合に, 環境適応機能は, ソフトウェア設定, ソフトウェア/ハードウェア構成を再構成する。

ソフトウェア設定変更は, Step4-5 処理を, 周期的, 又 は，性能がある閾值以下となった場合に試行模擬し，性 能向上やコスト低減度合を計算する。リソース量変更や 配置場所変更で性能やコストが改善できる見込みがある 場合は，ユーザに再構成を提案する。

ソフトウェア/ハードウェア構成変更は, Step1-3 処理 を, 周期的, 又は, 性能が閾值以下となった場合に試行 模擬し, コード変換して, GPU オフロード部分のロジッ ク変更や FPGA のハードロジックの変更(16)を行う。性 能やコスト改善の見込みがある場合は，ユーザに再構成 を提案する。ユーザ了承を得て, 再構成を実施する際に, GPU オフロード部分の変更等, ソフトウェア構成変更の 場合は，実行ファイルを起動する環境を複製後，クラウ ド技術(17)-(19)を用いてデータをマイグレーションする。

効果を考察する。Step3 は, ユーザにとって高性能化に よりサーバ数を減らせ設備コスト減効果がある。Step4も, 効率的にサーバ数を設定でき, 設備コスト減効果がある。 Step5 は,クラウドだけでなくエッジ等の最適配置により 応答時間減効果がある。Step7 は, オフロード部再構成に
よる性能改善で，増設コスト減効果がある。

\section{4.おわりに}

本稿では, GPU, FPGA 等を適切に活用し高性能を実 現するため, アプリケーションを配置環境に適応させる, 環境適応ソフトウェアの全体フローを提案した。

\section{文献}

(1) AWS EC2 web site, https://aws.amazon.com/ec2/instance-types/

(2) Y. Yamato, et al., "Predictive Maintenance Platform with Sound Stream Analysis in Edges," Journal of Information Processing, Vol.25, 2017

(3) Tron project web site, http://www.tron.org/

(4) Y. Yamato, et al., "Proposal of Lambda Architecture Adoption for Real Time Predictive Maintenance," IEEE CANDAR 2016, 2016.

(5) K. Ishizaki, "Transparent GPU exploitation for Java," CANDAR 2016.

(6) Y. Yamato, "Study of parallel processing area extraction and data transfer number reduction for automatic GPU offloading of IoT applications," Journal of Intelligent Information Systems, Springer, 2019.

(7) Clang website, http://llvm.org/

(8) gcov website, http://gcc.gnu.org/onlinedocs/gcc/Gcov.html

(9) gprof website, http://sourceware.org/binutils/docs-2.20/gprof/

(10) Deckard web site, http://github.com/skyhover/Deckard

(11) Y. Yamato, et al., "Automatic GPU Offloading Technology for Open IoT Environment," IEEE Internet of Things Journal, Sep. 2018.

(12) ROSE website, https://github.com/rose-compiler/rose-develop

(13) K. Shirahata, et al., "Hybrid Map Task Scheduling for GPU-Based Heterogeneous Clusters," IEEE CloudCom2010, 2010

(14) Jenkins web site, https://jenkins.io/

(15) Y. Yamato, "Automatic verification technology of software patches for user virtual environments on IaaS cloud," Journal of Cloud Computing, Springer, 2015, 4:4, Feb. 2015

(16) Y. Yamato, "Server Selection, Configuration and Reconfiguration Technology for IaaS Cloud with Multiple Server Types," Journal of Network and Systems Management, Springer, Aug. 2017.

(17) Y. Yamato, et al., "Fast and Reliable Restoration Method of Virtual Resources on OpenStack," IEEE Trans. on Cloud Computing, 2015.

(18) Y. Yamato, "Cloud Storage Application Area of HDD-SSD Hybrid Storage, Distributed Storage and HDD Storage," IEEJ Transactions on Electrical and Electronic Engineering, Vol.11, pp.674-675, 2016.

(19) Y. Yamato, "Use case study of HDD-SSD hybrid storage, distributed storage and HDD storage on OpenStack," ACM IDEAS 2015, 2015.

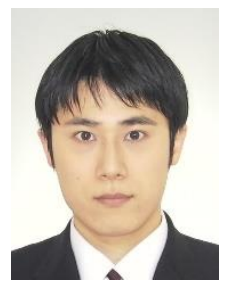
山登庸次

2000 年東京大学理学部卒。2009 年同大大学院総 合文化研究科にて博士 (学術)。2002 年日本電信電 話株式会社入社。同社にて, クラウド基盤技術, IoT 技術研究開発に従事。現在，同社 NTT ネットワー クサービスシステム研究所特別研究員。 